Proc. Estonian Acad. Sci. Geol., 2002, 51, 4, 227-240

\title{
Mineralogy of Morasko meteorite and the structure of the craters
}

\author{
Wojciech Stankowski ${ }^{\mathrm{a}}$, Andrzej Muszyński ${ }^{\mathrm{a}}$, Kevin Klimm ${ }^{\mathrm{b}}$, \\ and Manfred Schliestedt ${ }^{b}$ \\ a Institute of Geology, Adam Mickiewicz University, Maków Polnych 16, 61-606 Poznań, Poland; \\ stawgeo@amu.edu.pl; anmu@amu.edu.pl \\ b Institute of Mineralogy, Hannover University, Welfengarten 1, 30167 Hannover, Germany; \\ klimm@mineralogie.uni-hannover.de; schliestedt@mineralogie.uni-hannover.de
}

Received 3 April 2001, in revised form 5 March 2002

\begin{abstract}
This paper presents the results of geomorphological investigations of bowl-shaped hollows in "Rezerwat Meteoryt Morasko" - Morasko Meteorite Nature Reserve - of Poland and of mineralogical studies of recently found meteorites and micrometeorites. The meteorite shower fell between 5000 and $3500 \mathrm{BP}$, forming craters in the Morasko area. The age interval for this event was estimated by earlier palynological and ${ }^{14} \mathrm{C}$ studies. The Morasko meteorite is an iron type octahedrite (IAB group) which shows strong reheating effects. The investigated area is unique, because the material from space and the geomorphological effects of its fall can be identified there.
\end{abstract}

Key words: meteorite craters, iron meteorite, micrometeorites, Morasko, Poland.

\section{INTRODUCTION}

The Morasko Meteorite Nature Reserve (Polish "Rezerwat Meteoryt Morasko") lies northeast of Moraska Góra, the highest hill in the vicinity of Poznań, Poland (Fig. 1). Studies of iron meteorites from Morasko date back to 1914 (Pokrzywnicki 1955, 1956; Classen 1978; Pilski \& Walton 1999; Stankowski 2001). Pokrzywnicki initiated scientific study of both the meteorites and the morphological effects presumably caused by their fall. In the 1970 s, international interdisciplinary investigations were carried out in the area of the Morasko Meteorite Nature Reserve. This research resulted in publications ranging from theoretical considerations, through discussions on the trajectories, compositions, and structures of meteorites (Dominik 1976; Hurnik 1976; Hurnik et al. 1976), to geologicalgeomorphological studies on the origin of the bowl-shaped hollows found in the 


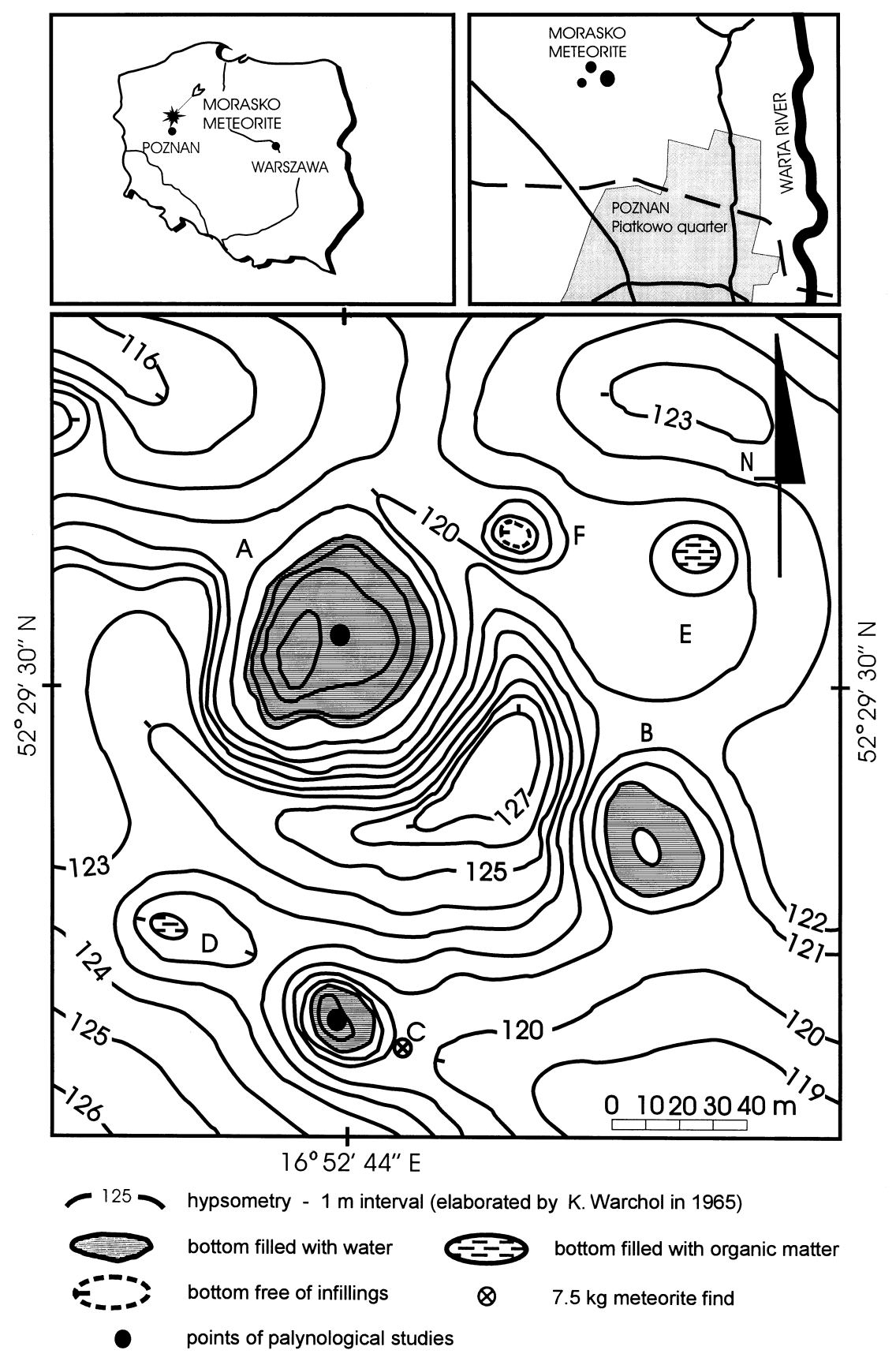

Fig. 1. Location of the Morasko Meteorite Nature Reserve and investigated craters (A-F). 
area. Hurnik et al. (1976) and Kuźmiński (1976) interpreted these hollows as impact related, but Karczewski (1976) treated them as glaciokarst features, i.e. arising from the melting of dead ice blocks. Tobolski (1976) presented the results of a palynological study of two organic sedimentary profiles from hollows A and C (Fig. 1). He established that the organic sediments started to accumulate not earlier than in the middle of the Atlantic chronozone, between 5500 and 5000 BP. The research done by the authors proved the impact origin of six hollows from the northeastern slope of Moraska Góra. This is supported by the age of the oldest organic sediments inside them $\left({ }^{14} \mathrm{C}\right.$ data $\left.3360 \pm 100,2690 \pm 170 \mathrm{BP}\right)$, as well as by the presence of meteorites and micrometeorites. There are records of micrometeorite protoliths of maghemite and goethite. Weathered shells on the meteorites have the same composition (absence of nickel). The meteorite shower fell into loose and loosely coherent deposits, thus neither impact breccia nor any high-pressure minerals or glass have been found. Nevertheless, shock-pressure structures in few quartz grains were observed.

\section{THE ORIGIN OF THE MORASKA GÓRA COMPLEX AND THE DEVELOPMENT OF METEORITE CRATERS}

The Moraska Góra complex is composed of Quaternary till, sand-and-gravel, and fine-grained sediments of the late Miocene Poznań series, all deformed by glaciotectonic processes (Karczewski 1961, 1976; Krygowski 1961, 1964). The deformations did not occur during the last glacial period (as postulated in Karczewski 1961), but probably before the last glacial advance (the Baltic ice cover of the Vistulian glaciation). We support the concept of Krygowski (1960, $1961,1964)$ that old geological structures in young glacial topography, such as the Moraska Gora complex (in terms of both the formation of its internal structure and the existence of the palaeomorphological rise), should be dated to the Middle Polish glacial period (Saale).

During the maximum extent of the last ice-sheet, the so-called Leszno Phase (about $20000 \mathrm{BP}$ ), shallow young deformations, and ice abrasion surfaces developed. A subglacial meltwater erosional topography began to form. Evorsion, along with active erosion by meltwaters and accumulation of glacigenic sediments, continued in the so-called Poznań Phase (about 17 000-18 000 BP). Beyond the glacial cover, permafrost existed and active periglacial processes occurred.

Ice-sheet recession and later permafrost degradation led to the formation of kettle holes through the melting of dead ice blocks. The organic infilling of these kettle holes began c. $14000 \mathrm{BP}$.

Between 5000 and 3500 BP the Morasko meteorite shower fell, forming craters. Neither impact breccia nor high-pressure minerals or glass have been discovered in the loose and loosely coherent Quaternary and Tertiary deposits. Conditions suitable for the development of organic sediments, including peat, occurred at a different time in hollows $\mathrm{A}-\mathrm{E}$ and lasted for various periods. 


\section{THE RESULTS OF GEOMORPHOLOGICAL STUDIES}

Based on previous studies (Karczewski 1976; Tobolski 1976), the authors performed new research with the hand-drilled cores from each hollow (see Fig. 2). The properties of the accumulated sediments were established and their bottom organic layers dated by the radiocarbon method (all data were supplied by the Department of Radioisotopes Application of the Silesian Technical University in Gliwice).

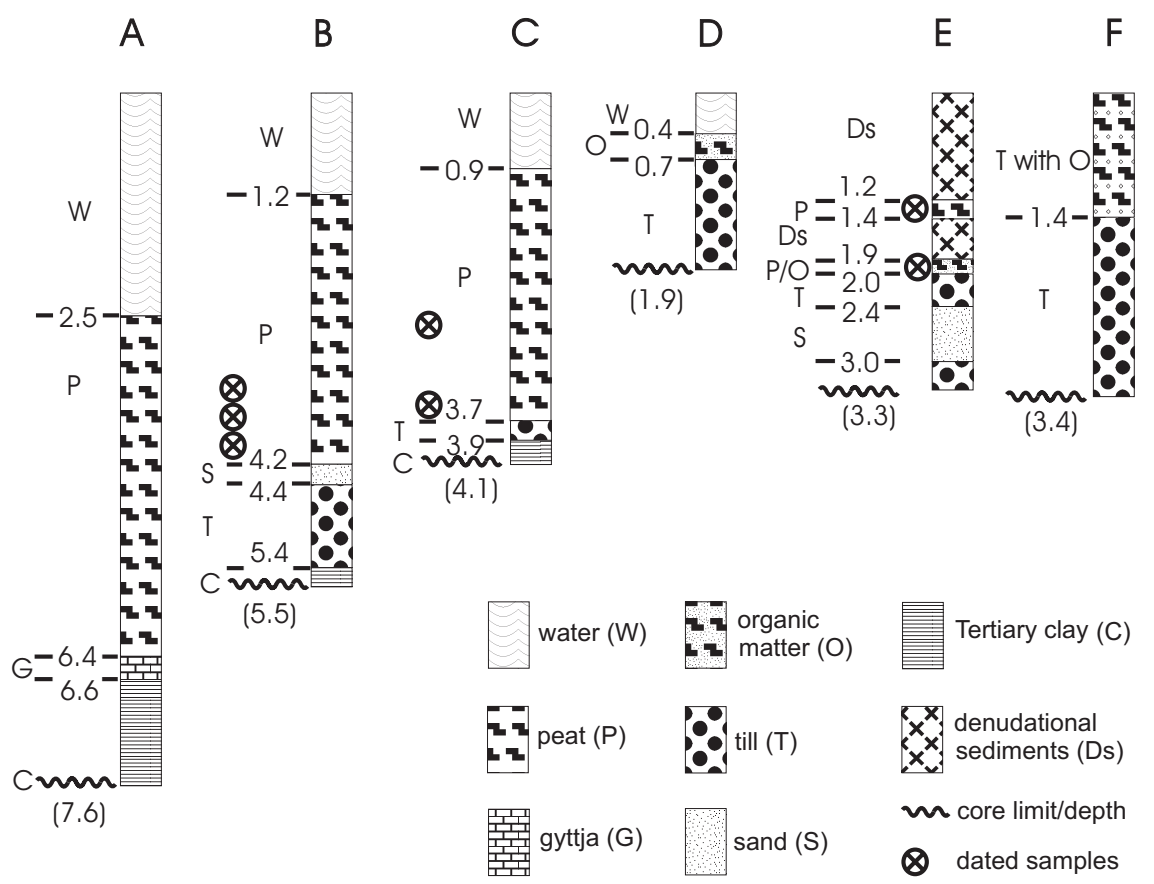

Fig. 2. Simplified profiles of sediments from the middle parts of the hollow bottoms (A-F; hand drillings from the ice cover in winter). Depths to the left of the columns are in metres.

The organic sedimentation took place in each hollow at a different time interval (Fig. 3). In hollows A, B, and E (Fig. 1) sedimentation began a few thousand years ago. In $\mathrm{C}$ and $\mathrm{D}$ the onset of organic infilling was less than 1000 years ago. Hollow $\mathrm{F}$ is dry and hosts no bottom organic layer (see Figs. 1, 2). Such difference is caused by subsurface lithological variations which are partly due to glaciotectonic deformations of Quaternary and Tertiary deposits - till, clay, and sand with gravel and different hydrological conditions.

The organic infilling was continuous only in hollows $\mathrm{A}$ and $\mathrm{B}$, and dispersed in others. The log of hollow E (Fig. 2) is particularly interesting as it hosts organic 


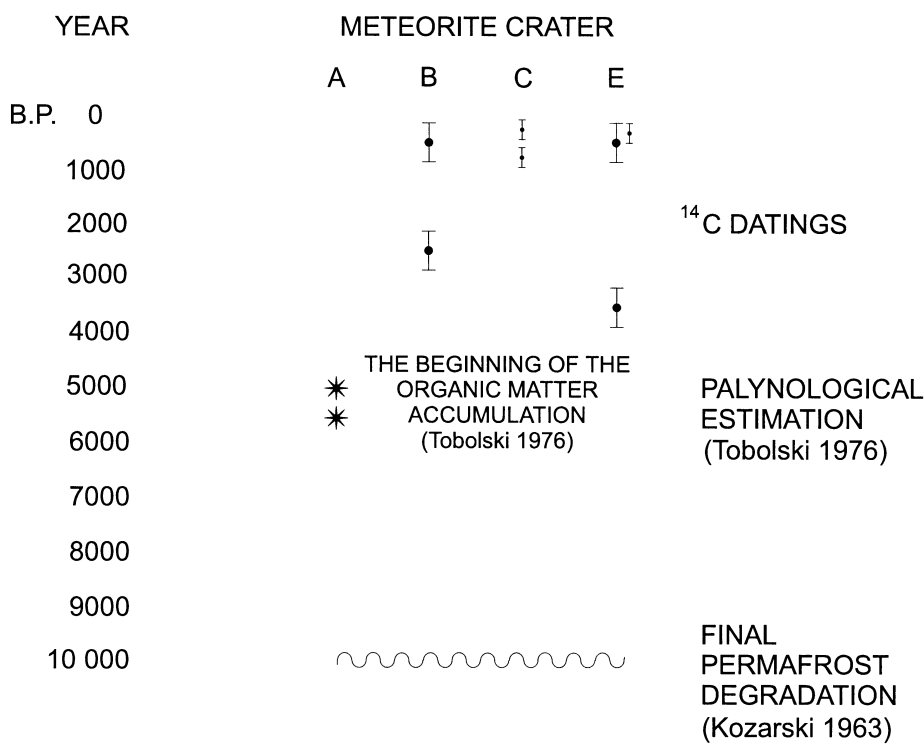

Fig. 3. Radiocarbon datings of the organic infillings of Moraska Góra meteorite craters.

sediments in two levels separated by mineral matter. The deeper organic layer is dated at $3360 \pm 100 \mathrm{BP}$, the shallower at $610 \pm 75 \mathrm{BP}$.

The deeper organic layer from hollow E gave the oldest age of $3360 \pm 100 \mathrm{BP}$. The second oldest date, $2690 \pm 170 \mathrm{BP}$, was that of the bottom of the organic sediments from hollow B. Both dates are considerably younger than the age of the lowermost organic sediments in hollow A by palynological data - about 5000 or even 5500 years ago (Tobolski 1976).

The remaining dates (hollow $\mathrm{C}$ and two dates from the upper part of hollow $\mathrm{B}$ ) are not older than 1000 years. They belong to the same period as the shallower organic interbedding in hollow E. It is possible that large amounts of organic matter began to accumulate in the investigated hollows not earlier than $700 \mathrm{BP}$. Dates ranging from 600 to $700 \mathrm{BP}$ are appropriate when matched with palaeoclimatological data, as the period of 1200-1400 AD was humid and could have been favourable for the growth of hygrophilous plants.

The results of earlier palynological tests (Tobolski 1976) and those of the radiocarbon datings due to this study differ distinctly. Yet, both of them seem to disprove the idea that the hollows under disscussion were produced by glaciokarst. The accumulation of the organic matter did not start before c. 5000-5600 BP, several thousand years later than the degradation of the permafrost in the area of the Great Poland Lowland some 10000 BP (Kozarski 1963). The Moraska Góra complex is part of the postglacial topography which acquired its final form during the Poznan stage of the so-called Baltic Glaciation - the last ice sheet of the North Polish (Vistulian) glacial period (Karczewski 1961; Kozarski 1986). 


\section{THE RESULTS OF MINERALOGICAL STUDIES}

A number of new meteorite fragments were recently found in the area north of the Morasko Meteorite Nature Reserve. About $80 \mathrm{~kg}$ of material was collected, whereas individual fragments weighed from a few hundred grams to several kilograms. All of them, particularly larger specimens, were covered by a rust-coloured weathered crust. Sediments near the meteorites were impregnated with ferrous compounds.

The laboratory investigations included magnetic separation of the micrometeorites, X-ray detection of the micrometeorites and weathered crusts, electron microprobe determination of their mineral composition, SEM semiquantitative analysis of micrometeorites, and microscopic examination in transparent and reflected light. The investigations were performed at the Mineralogical Institute of Hannover University, Germany, and at the Institute of Geology, Adam Mickiewicz University, Poland.

\section{The meteorites}

Microprobe analysis of seven polished sections (Table 1) yielded about 150 results, which are generally consistent with those published by Buchwald (1975) and Dominik (1976). The Morasko meteorite is a coarse-grained metallic octahedrite with many polymineral nodules, belonging according to Buchwald (1975) to group IAB (based on the assumption of a cooling rate of $1.8^{\circ} \mathrm{C}$ per million years, on the average germanium content of $40 \mathrm{ppm}$, and on the established value of the impact pressure of $130-750 \mathrm{~kb}$ ). Choi et al. (1995) reclassified the

Table 1. Selected microprobe analysis of the Morasko meteorite and micrometeorites (in per cent)

\begin{tabular}{|c|c|c|c|c|c|}
\hline & \multicolumn{2}{|c|}{ Meteorite } & \multicolumn{2}{|c|}{$\begin{array}{l}\text { Micrometeorites with low } \\
\text { Ni content }\end{array}$} & \multirow{2}{*}{$\begin{array}{c}\begin{array}{c}\text { Micrometeorite with high } \\
\text { Ni content }\end{array} \\
\text { Sample } 4 / \mathrm{KKH} \\
\end{array}$} \\
\hline & Kamacite & Taenite & Sample 3/11 & Sample P5/40 & \\
\hline $\mathrm{O}$ & & & 1.35 & 0.005 & 6.77 \\
\hline $\mathrm{Si}$ & & & 1.18 & 0.004 & 0.64 \\
\hline S & 0.02 & 0.01 & 0.01 & 0.001 & \\
\hline $\mathrm{Fe}$ & 95.42 & 80.49 & 55.93 & 62.97 & 87.04 \\
\hline $\mathrm{Ni}$ & 6.49 & 18.08 & 0.001 & 0.001 & 4.66 \\
\hline $\mathrm{Mg}$ & & & & & 0.05 \\
\hline $\mathrm{Al}$ & & & & & 0.57 \\
\hline $\mathrm{Mn}$ & & & & & 0.27 \\
\hline Total & 101.1 & 98.6 & $58.47 *$ & $62.98^{*}$ & 100.0 \\
\hline $\mathrm{Fe}_{3} \mathrm{O}_{4}$ & & & 77.2 & 86.9 & \\
\hline $\mathrm{FeOOH}$ & & & 88.9 & 100.1 & \\
\hline
\end{tabular}


Morasko meteorite as belonging to IIICD class. Main iron-nickel minerals are kamacite and taenite. Minor minerals include schreibersite, rhabdite, troilite, cohenite, graphite, and sphalerite (Buchwald 1975; Dominik 1976). The mean nickel content of the Morasko meteorite is $6.8 \%$.

Studying the mineral composition and structure of the Morasko meteorite, Buchwald (1975) noticed that kamacite had locally undergone an extensive change to a granular pattern, and the cohenite crystals had markedly recrystallized. Such patterns provide significant evidence that the fall of the meteorite was accompanied by shock transformations similar to those described for the Canyon Diablo (USA) and Kaali (Estonia). The microstructure of the investigated samples from the Morasko meteorite particularly resembles that of the specimens obtained from the Canyon Diablo, which were subjected to a low degree of reheating following a medium-force impact (Buchwald 1975). Pilski \& Walton (1999) confirmed the effects of reheating due to the impact of the Morasko meteorite, particularly in several small specimens which are kept at the museum of the Olsztyn Planetarium.

Buchwald (1975) and Czegka (1996) argue that the Morasko meteorite is similar to the meteorite from Przełazy near Sulechów (internationally known as the Seeläsgen meteorite). R. Bartoschewitz (pers. comm., 2001) confirms that the Morasko meteorite fall should be paired with the Przełazy and Tabarz meteorites, and could possibly be the broadest strewn field of meteorites known in the world.

\section{The slag}

The presence of possible meteoritic slag in the vicinity of the Morasko Meteorite Nature Reserve is the subject of separate research. The slag matter is strongly magnetic and differs from that of the meteorite only in its visible porosity. After etching with Nital (nitric acid solution in ethylene alcohol), the material does not show Widmanstätten structures, which are characteristic of the iron meteorites.

In support of the statement that some material found in the vicinity of the Morasko Meteorite Nature Reserve is a kind of anthropogenic slag, we also refer to the unpublished results of chemical analyses by R. Bartoschewitz (pers. comm., 1998). Hurnik \& Kuźmiński (1983), studying the Godzięcin area, and Muszer (1998), studying the Brzeg Dolny area, obtained similar results in tests on the slag.

\section{The micrometeorites}

The micrometeorites were separated by a hand magnet, and the grains obtained from various fractions were subjected to light microscope, XRD, microprobe, and SEM examinations. It was established that the spatial distribution of the micrometeorites in the Morasko Meteorite Nature Reserve reached its eastern and 
northern borders. The frequency and density of the distribution of the micrometeorites vary remarkably, with the highest densities occurring at the sites where large meteoritic fragments are found (Wysocka 1998; Piszczała 1999; Derdowski 2000).

In their earlier study of the distribution of the meteoritic dust, B. Hurnik \& H. Hurnik (pers. comm., 1996) assumed that the quantity of ablative spherules should be particularly large beneath the path of the meteoroid, up to the site of its fall, i.e. north of the craters. This assumption was partly confirmed by the results of their study.

We found that the magnetically separated micrometeorites from the Morasko area were of various shapes and of a rusty colour. In characteristics they resemble the spherules from the Kaali crater (Estonia), described by Raukas et al. (1995), Raukas $(1997,2000)$, and the spherules collected from different impact sites worldwide (Peters 1984; Glass 1990, 1997). The most frequent shapes are those of cylinders, ellipsoids or other solids with an oval plane section, or tapered bodies (icicles). Spherical or irregular shapes and broken fragments are less common (Fig. 4a,b). An SEM examination also revealed spherical forms which are interconnected or clustered in bunches. A characteristic of the discussed meteoritic dust is that its particles, when broken into halves, are hollow (Fig. 4c).

Two different chemical compositions of the spherules can be distinguished:

1. ferric compounds (goethite and maghemite, with small amounts of lepidocrocite) which were originally $\mathrm{Fe}-\mathrm{Ni}$ alloys or magnetite: these spherules are micrometeorites (Table 1);

2. glassy silicates (these spherules are probably microtektites), produced by a partial fusion of extraterrestrial and terrestrial matter at the moment of the impact explosion of the meteorite.

The chemical composition and phases confirm that the micrometeorites from the Morasko area mainly contain maghemite and goethite, with small amounts of magnetite and lepidocrocite (Table 1). The small quantity of Si identified by chemical analyses is possibly due to an admixture of detrital quartz grains. The contents of $\mathrm{Ni}$ and $\mathrm{S}$ are low, amounting to no more than $0.01-0.12 \%$ and $0.01-0.05 \%$, respectively, which suggests advanced weathering and the leaching of the two elements from the weathered crust (Buchwald \& Clarke 1989; Golden et al. 1995). But a few examined micrometeorite grains contain a metallic core displaying the same Ni content as the meteorite (c. 5-6\%) (Derdowski 2000). The $\mathrm{Ni}$ content decreases gradually toward the rim of the micrometeorite grain, resembling the behaviour of $\mathrm{Ni}$ from the weathered skin of the meteorite itself (Fig. 5). The rims of such grains are altered to iron oxides.

The possible development of mineral phases during the weathering of an iron meteorite is presented in Fig. 6. At this stage of the transformation, the most stable final phases are maghemite and goethite. X-ray and SEM examinations of the micrometeorite and the weathered crust of the meteorite revealed very similar mineral and chemical compositions of the two materials. The closer to the surface 

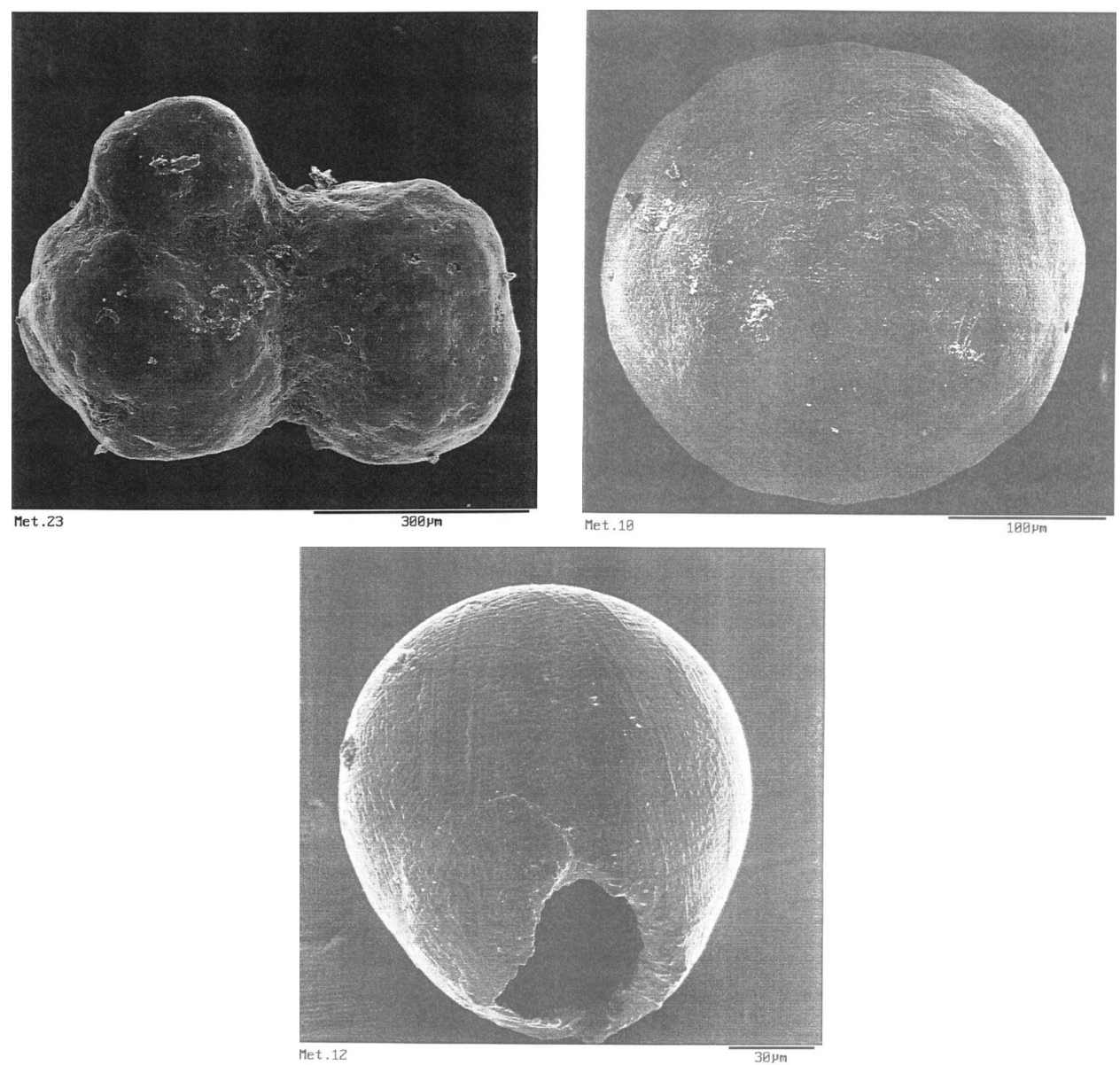

Fig. 4. Selected SEM photos of the micrometeorites from the area north of the Morasko Meteorite Nature Reserve.

of the crust of the meteorite, or the further away from the pure metal, the lower the Ni content. The end product of the weathering of the crust of the meteorite is the same as the material of the weathered micrometeorites, which is the evidence of their common origin.

Further investigation focusing on locating the mineralogical evidence of the impact (following the methods of Clymer et al. 1996 and Langenhorst 1996) included a search for planar deformation features (PDF) in the quartz and feldspar grains. The preliminary results of this study were not satisfactory, although a few microscopic images of quartz grains containing structures similar to the PDF produced by the shock of impact were obtained. This course of investigation shall be continued, since the study of the Wabar meteorite of similar size, which fell in a sandy desert, gave good results (Wynn \& Shoemaker 1999). 

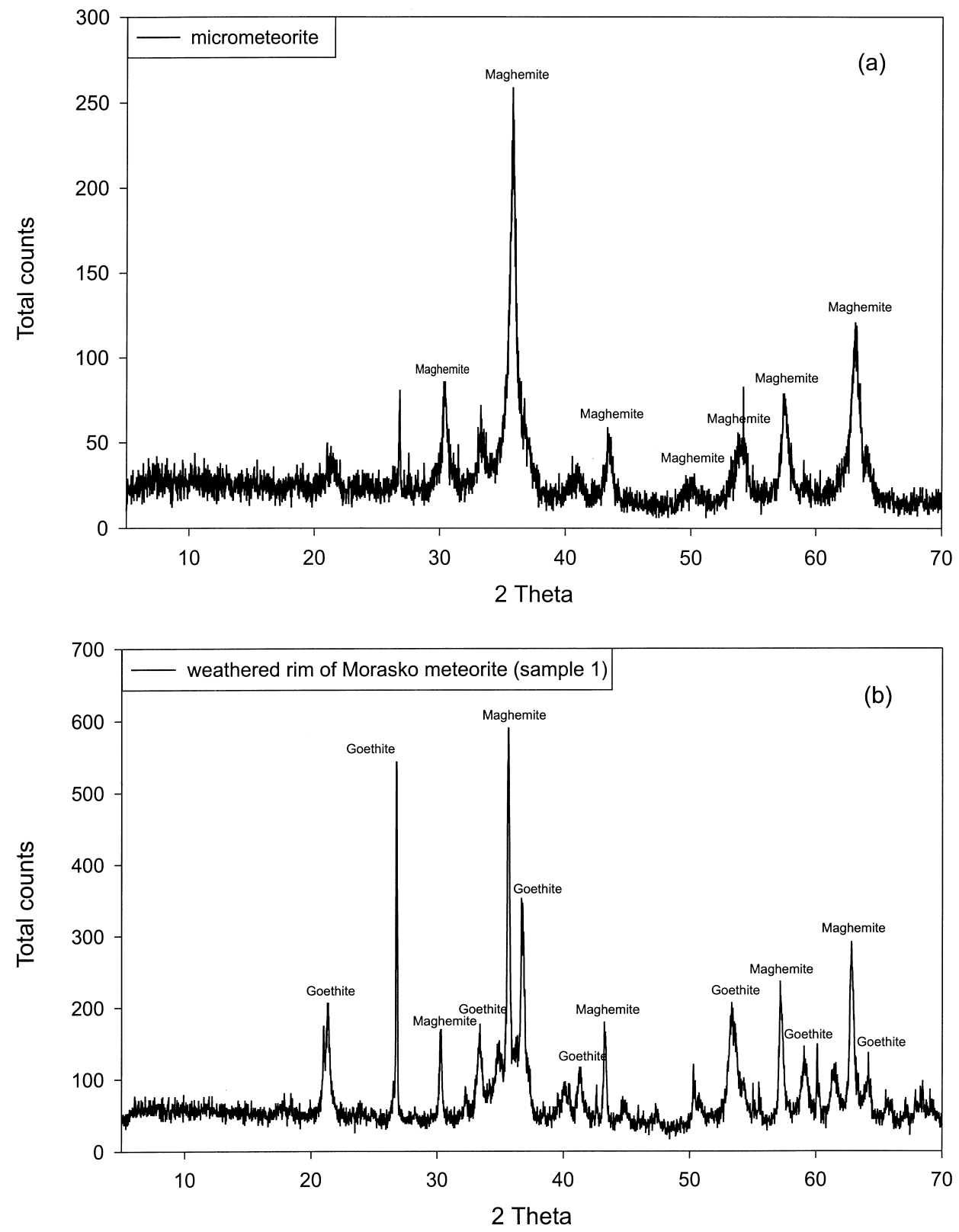

Fig. 5. The XRD ( $\mathrm{Cu}$ radiation) patterns of the micrometeorite (a) and the skin of the weathered meteorite fragment (b), showing the same maghemite and goethite compositions. 


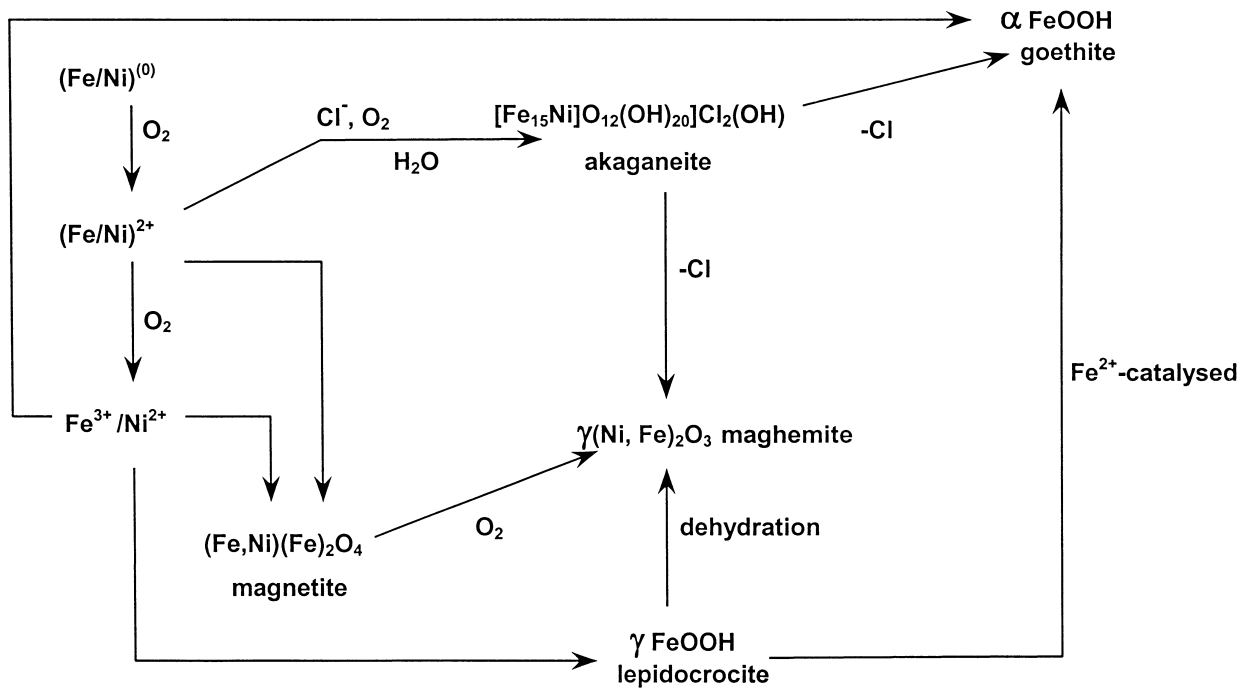

Fig. 6. Schematic representation of some of the possible pathways of the formation of various oxide phases in the Hoba weathering crust. Ni can be a substituent in all these oxides (after Golden et al. 1995).

\section{FINAL REMARKS}

The Morasko meteorite shower formed at least six craters. According to palynological data the craters formed before 5000-5600 years ago. According to our ${ }^{14} \mathrm{C}$ data, they seem to be younger, but clearly more than $3500 \mathrm{BP}$. However, the beginning of organic matter accumulation cannot be identified precisely, because the organic infilling of the craters started in the hollows at a different time.

The origin of the micrometeorites is related to the fall of the meteorite. Their mineral and chemical compositions are very similar to those of the weathered crust of the meteorite skin. Several micrometeorite grains have unaltered kamacite cores, which is an additional evidence for their common origin with the meteorite fragments. The matter of the slag requires further mineralogical investigations. The Morasko area suits well for complex studies because here extraterrestrial material occurs along with the clearly recognizable geomorphological effects of meteorite fall.

\section{ACKNOWLEDGEMENTS}

This study was supported by the Polish State Committee for Scientific Research (KBN) (grants Nos. 6 PO4E 05510 and 6 PO4E 008 20), DAAD, and parent institutions of the authors. The authors thank Jüri Plado and Kalle Suuroja for their constructive reviews and Derek Handley for improving the Englich text. 


\section{REFERENCES}

Buchwald, V. F. 1975. Handbook of Iron Meteorites. Univ. California Press, Berkeley, California.

Buchwald, V. R. \& Clarke, R. S., Jr. 1989. Corrosion of Fe-Ni alloys by Cl-containing akaganéite ( $\gamma$-FeOOH): The Antarctic meteorite case. Amer. Mineral., 47, 656-667.

Classen, J. 1978. The meteorite craters of Morasko in Poland. Meteoritics, 13, 245-255.

Clymer, A. K., Bice, D. M. \& Montanari, A. 1996. Shocked quartz from the late Eocene: impact evidence from Massingano, Italy. Geology, 26, 483-486.

Choi, B.-G., Ouyang, X. \& Wasson, J. T. 1995. New analysis, reclassification from IAB to IIICD proposed. Geochim. Cosmochim. Acta, 59, 593-612.

Czegka, W. 1996. Das holozäne Meteoritenkraterfeld von Morasko bei Posen (Polen). Aufschluss, 47, 165-185.

Derdowski, R. 2000. Budowa geologiczna północnej części rezerwatu „Meteoryt Morasko” oraz charakterystyka mineralogiczna mikrometerytów i szlak znajdowanych na tym obszarze. Unpubl. MSc. thesis. Instytut Geologii UAM.

Dominik, B. 1976. Mineralogical and chemical study of coarse octahedrite Morasko (Poland). Prace Mineral., 47, 61.

Glass, B. P. 1990. Tektites and microtektites. Key facts and inferences. Tectonophysics, 171, 393404.

Glass, B. P. 1997. Cenozoic impact spherule layers. In Impact and Extraterrestrial Spherules: New Tools for Global Correlation. International Symposium, IGCP Project 384, 1-5 July 1997, Excursion Guide and Abstracts (Raukas, A., ed.), pp. 26-27. Tallinn.

Golden, D. C., Ming, D. W. \& Zolensky, M. E. 1995. Chemistry and mineralogy of oxidation products on the surface of the Hoba nickel-iron meteorite. Meteoritics, 30, 418-422.

Hurnik, H. 1976. Meteorite "Morasko" and the region of the fall of the meteorite. In Meteorite Morasko and Region of Its Fall. Uniw. Adama Mickiewicza Poznan, Ser. Astronomia, 2, 3-6.

Hurnik, H., Korpikiewicz, H. \& Kuźmiński, H. 1976. Distribution of the meteoritic and meteor dust in the region of the fall of the meteorite "Morasko". In Meteorite Morasko and Region of Its Fall. Uniw. Adama Mickiewicza Poznan, Ser. Astronomia, 2, 27-37.

Hurnik, B. \& Kuźmiński, H. 1983. Czy w okolicach Godzięcina nastapił spadek meteorytu? Postepy Astronomii, 31, 315-318.

Karczewski, A. 1961. Morasko Hill. Example of a terminal push moraine of the Poznan Stage. In Guide-Book of Excursion A, The Great Poland Lowland, VI INQUA Congress, Poland, August-September 1961 (Krygowski, B., ed.), pp. 21-22. NWN Oddz. Łódź.

Karczewski, A. 1976. Morphology and lithology of closed depression area located on the northern slope of Morasko Hill near Poznań. In Meteorite Morasko and Region of Its Fall. Uniw. Adama Mickiewicza Poznan, Ser. Astronomia, 2, 7-19.

Kozarski, S. 1963. O późnoglacjalnym zaniku martwego lodu w Wielkopolsce Zachodniej. Bad. Fizjogr. nad Polska Zach., 11, 51-59.

Kozarski, S. 1986. Skale czasu a rytm zdarzeń geomorfologicznych vistulianu na Niżu Polskim. Czas. Geogr., 57, 247-270.

Krygowski, B. 1960. Old structures in young endmoraines. Przegl. Geogr., 32 (Suppl.), 51-55.

Krygowski, B. 1961. The Great Poland Lowland. In Guide-Book of Excursion A, The Great Poland Lowland, VI INQUA Congress, Poland, August-September 1961 (Krygowski, B., ed.), pp. 7-19. NWN Oddz. Lódź.

Krygowski, B. 1964. O przetrwałości stref glacitektonicznych. Zesz. Nauk. Uniw. A. Mickiewicza, Geografia, 4, 99-103. 
Kuźmiński, H. 1976. Dynamic elements of the meteoritic shower „Morasko”. In Meteorite Morasko and Region of Its Fall. Uniw. Adama Mickiewicza Poznan, Ser. Astronomia, 2, 45-63.

Langenhorst, F. 1996. Characteristics of shocked quartz in Late Eocene impact ejecta from Massigano (Acona, Italy): Clues to shock conditions and source crater. Geology, 24, 487490.

Muszer, A. 1998. Charakterystyka petrograficzno-mineralogiczna rud Fe i półproduktów metalurgicznych ze stanowiska archeologicznego „Przylesie Dolne”. Acta Univ. Wratis. Prace Geol. Min., 67, 45-60.

Peters, R. J. 1984. Mikroanalytische Untersuchungen an einzeln Staubkörnen aus dem Schefeis der Antarktis. PhD thesis, Univ. Köln.

Pilski, A. S. \& Walton, W. 1999. Morasko - the largest European iron meteorite shower. Meteorite, 5, 27-28.

Piszczała, E. 1999. Mineralogia osadów wokół kraterów impaktowych z rejonu rezerwatu Morasko. Unpubl. MSc thesis, Instytut Geologii UAM.

Pokrzywnicki, J. 1955. O niektórych mało znanych polskich meteorytach. Acta Geol. Polonica, 5, $427-437$.

Pokrzywnicki, J. 1956. Les Météorites Polonaises. Acta Geophys. Polonica, 4, 21-32.

Raukas, A. (ed.). 1997. Impact and Extraterrestrial Spherules: New Tools for Global Correlation. International Symposium, IGCP Project 384, 1-5 July 1997, Excursion Guide and Abstracts. Tallinn.

Raukas, A. 2000. Study of meteoritic matter for precise regional stratigraphy. Geologos, 5, 77-86.

Raukas, A., Pirrus, R., Rajamäe, R. \& Tiirmaa, R. 1995. On the age of the meteorite craters at Kaali (Saaremaa Island, Estonia). Proc. Estonian Acad. Sci. Geol., 44, 177-183.

Stankowski, W. T. J. 2001. The geology and morphology of the natural reserve "Meteoryt Morasko". Planet. Space Sci., 49, 749-753.

Tobolski, K. 1976. Palynological investigations of bottom sediments in closed depressions. In Meteorite Morasko and Region of Its Fall. Uniw. Adama Mickiewicza Poznan, Ser. Astronomia, 2, 21-26.

Wynn, J. C. \& Shoemaker, E. M. 1999. Kiedy piaski zajaśniały ogniem. Świat Nauki, 89, 48-55.

Wysocka, A. 1998, Litologia i petrografia osadów wschodniego sąsiedztwa rezerwatu „Meteoryt Morasko". Unpubl. MSc thesis, Instytut Geologii UAM.

\title{
Morasko meteoriidi mineraloogia ja kraatrite ehitus
}

\author{
Wojciech Stankowski, Andrzej Muszyński, Kevin Klimm \\ ja Manfred Schliestedt
}

Morasko meteoriidi ja meteoriidikraatrite uurimine samanimelisel looduskaitsealal pakub unikaalseid võimalusi paljude meteoriitikaalaste probleemide lahendamiseks. Meteoriidisadu kujundas selles piirkonnas kuus suuremat kraatrit, mille morfoloogiat ja täitematerjali on põhjalikult uuritud. Oktaedriitide IAB rühma kuuluvast meteoriidist on tehtud keemilised analüüsid ja teda on uuritud veel mitmete meetoditega, sealhulgas skaneeriva elektronmikroskoobi ja mikrosondi abil. Vanima orgaanikakihi vanuseks kraatris A on saadud $3360 \pm 100$ aastat, mis näitab, et kraatrid kujunesid vähemalt 3500 aastat tagasi. 


\title{
Минералогия метеорита Мораско и строение кратеров
}

\author{
Войцех Станковский, Анджей Мушиньский, Кевин Климм \\ и Манфред Шлистедт
}

\begin{abstract}
Изучение метеорита Мораско и его кратеров представляет уникальную возможность для решения множества проблем метеоритики. В результате падения метеорита образовалось шесть кратеров, морфология которых и заполняющие их осадки тщательно изучены. Метеорит, который представляет собой октаэдрит группы IАВ, исследовали при помощи химического анализа, а также другими методами, в том числе сканирующим электронным микроскопом и микрозондом. Для древнейшего слоя органики в кратере А получен возраст $3360 \pm 100$ л. н., что указывает на падение метеорита по крайней мере 3500 л. н.
\end{abstract}

